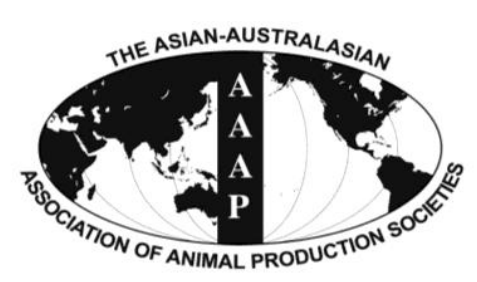

Open Access

Asian Australas. J. Anim. Sci.

Vol. 28, No. 3 : 318-322 March 2015

http://dx.doi.org/10.5713/ajas.14.0927

www.ajas.info

pISSN 1011-2367 elSSN 1976-5517

\title{
Studies on Intramuscular Fat Percentage in Live Swine Using Real-time Ultrasound to Determine Pork Quality
}

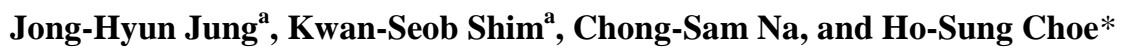 \\ Department of Animal Biotechnology, Chonbuk National University, Jeonju 561-756, Korea
}

\begin{abstract}
In the modern pork industry, selection of high intramuscular fat (IMF) in pigs is necessary to improve pork quality. Ultrasound has been used previously to predict subcutaneous fat thickness and IMF in the longissimus muscles of line pigs and Realtime ultrasound has also been reported as a reliable method for estimating IMF in live pigs. So we estimate the correlation between meat quality traits and IMF percentage to investigate the possibility of utilizing real-time ultrasound technology for predicting IMF percentage in line pigs to improve pork quality. The genetic and phenotypic correlations for chemical intramuscular fat (CIMF) and ultrasound intramuscular fat (UIMF) were estimated to be 0.75 and 0.76 , respectively. These results suggest that genetic factors strongly influence meat quality. The genetic and phenotypic correlation between UIMF and CIMF were $0.75,0.76$, respectively. The heritability of UIMF and CIMF were 0.48 and 0.50 , respectively. So we concluded that CIMF can be replaced with UIMF and Ultrasound machines can be used to test IMF in live swine. In future, UIMF can be utilized to improve pork quality as an alternative to CIMF. (Key Words: Pork Quality, Realtime Ultrasound, Intramuscular Fat, Heritability, Genetic Correlation)
\end{abstract}

\section{INTRODUCTION}

The modern pork industry has evolved toward high meat and low fat percentage pigs. This has resulted in lower quality pork characterized by lack of tenderness, juiciness, and flavor (Barton-Gade, 1990). Marbling affects tenderness, juiciness and flavor, all indicators of pork quality (Brewer et al., 2001). Schworer et al. (1995) reported that the selection of high intramuscular fat (IMF) in pigs is necessary to improve pork quality. Ultrasound has been used previously to predict subcutaneous fat thickness and IMF in the longissimus muscles of line pigs (Moeller, 1994; Regland et al., 1997). Real-time ultrasound has also been reported as a reliable method for estimating IMF in live pigs (Newcom et al., 2002).

The use of real-time ultrasound to measure backfat thickness and loin muscle area in swine has been well documented. Recent developments in computer

\footnotetext{
* Corresponding Author: Ho-Sung Choe. Tel: +82-63-270-2513, Fax: +82-63-270-2614, E-mail: hschoe@jbnu.ac.kr

a These two authors contribute equally to this work.

Submitted Dec. 8, 2014; Revised Jan. 12, 2015; Accepted Feb. 4, 2015
}

technologies and color image processing techniques have improved the efficiency of measuring fat using computer image analysis (Albrecht et al., 1996; Basset et al., 2000; Yang et al., 2005). Additionally, recent real-time ultrasound technology in animal science and industry was applied to measure backfat thickness and loin muscle area in swine because ultrasound technology has several strongpoints as objectivity, low cost, its convenience, high accuracy, animal safety (Terry, 1989; Cross and Belk, 1994). In animal breeding programs, ultrasound technology increases accuracy of measurement of sirloin and fat thickness.

Korean consumers prefer high marbling and fatty pork over leaner alternatives. So we want to extend the application of ultrasound technology in animal science and industry through this study. To achieve this purpose, we compare ultrasound intramuscular fat (UIMF) to several commonly used pork quality measurements containing chemical intramuscular fat (CIMF). The objective of this study was to investigate the possibility of utilizing real-time ultrasound technology for predicting IMF percentage in line pigs to improve pork quality. 


\section{MATERIALS AND METHODS}

\section{Experimental animals}

Animal numbers per breed, sex, examination year, weight after examination were displayed in Table 1.

Data used for this study $(n=2,495)$ were collected from three pig breeding farms in Korea. Four breeds, Berkshire $(\mathrm{n}=1,345)$, Duroc $(\mathrm{n}=459)$, Landrace $(\mathrm{n}=245)$ and Large White $(n=446)$, of farm performance tested pigs were measured for IMF percentage using live animals and their pork quality trait records were collected.

\section{Analysis}

At an average weight of $114 \mathrm{~kg}$, pigs were scanned with an Aloka 500V SSD ultrasound machine (Corometrics Medical Systems, Inc., Wallingford, CT, USA) to measure their IMF percentage. A minimum of four longitudinal images (Figure 1) were collected at $7 \mathrm{~cm}$ off the midline across the 10th to the 13th ribs. The images were used to predict UIMF in accordance with the method proposed by Newcom et al. (2002).

Following a $\mathrm{pH}_{24 \mathrm{~h}}$ (24 hour chill after harvest, the ultimate $\mathrm{pH}$ ) was measured on the 10-rib face of the longissimus muscle using a $\mathrm{pH}$ star probe (Horiba 625210D, Irvine, CA, USA). At $24 \mathrm{~h}$ postmortem, a $3.2 \mathrm{~mm}$ slice of the loin beginning from the 10th- to the 11th-rib interface was analyzed for CIMF using Bligh and Dyer's method (1959). The frozen samples were thawed overnight at $4^{\circ} \mathrm{C}$ and trimmed, with $5 \mathrm{~mm}$ cut off the top to expose a fresh surface. The objective meat color (Commission Internationale de l'Eclairage [CIE]; lightness [L*], redness $\left[\mathrm{a}^{*}\right]$, yellowness $\left[\mathrm{b}^{*}\right]$ ) was measured after a $30 \mathrm{~min}$ blooming period at $4^{\circ} \mathrm{C}$ (CR-300, Minolta Camera Co, Osaka, Japan). Cooking loss (CL) and shear force (SF) measurements were obtained from approximately $350 \mathrm{~g}$ $(5 \times 6 \times 7 \mathrm{~cm})$ of meat blocks, trimmed and cooked in a $70^{\circ} \mathrm{C}$ water bath for 60 min until the sample block reached $70^{\circ} \mathrm{C}$. The cooked samples were cooled in $18^{\circ} \mathrm{C}$ running water for $30 \mathrm{~min}$. The SF was determined from an average of 6 cores taken from the cooked sample block using an Instron (Series IX, Instron Corp, Norwood, MA, USA). The measurement condition was $400 \mathrm{~mm} / \mathrm{min}$ head speed with

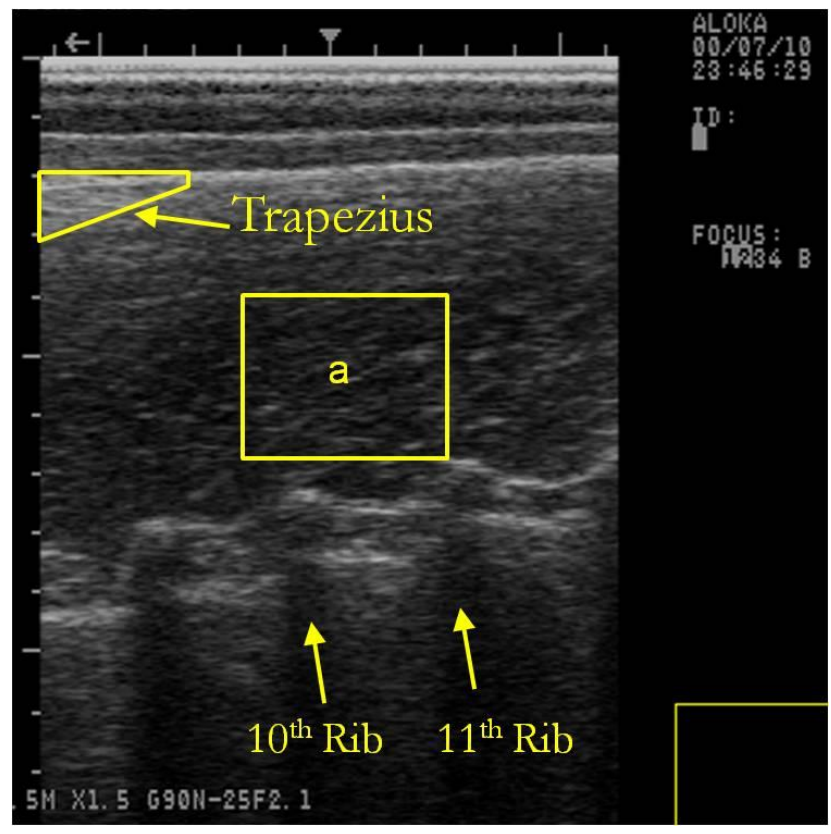

Figure 1. Example of an ultrasound image used for the prediction of intramuscular fat percentage. ${ }^{a}$ Region of interest: $100 \times 100$ pixel area. 10 image parameters generated from this region.

$40 \mathrm{~kg}$ load cells. Weight loss before and after cooking was expressed as a percent weight of the initial cooking block and ascribed to CL.

\section{Statistical analysis}

To estimate the effects of breed, sex, final weight, parity, birth year and birth month on productive traits, the collected data were statistically analyzed by the least squares method using the following linear model (Harvey, 1979).

$$
Y_{i j k l m}=\mu+B_{\mathrm{i}}+S_{j}+Y_{k}+W_{l}+e_{i j k l m}
$$

Where, $Y_{i j k l m}$ is the observation on the $i^{\text {th }}$ breed, $\mathrm{j}^{\text {th }}$ sex, $\mathrm{k}^{\text {th }}$ year of test and $\mathrm{l}^{\text {th }}$ final weight; $\mu$ is the population mean; $B_{i}$ is the effect of $i^{\text {th }}$ breed $(i=1,2,3,4) ; S_{j}$ is the effect of $j^{\text {th }} \operatorname{sex}(j=1,2) ; Y_{k}$ is the effect of $k^{\text {th }}$ year of test $(\mathrm{k}=1,2,3) ; \mathrm{W}_{\mathrm{l}}$ is the effect of $\mathrm{l}^{\text {th }}$ final weight $(\mathrm{l}=1,2,3,4$, $5)$; $\mathrm{e}_{\mathrm{ijklm}}$ is the residual error.

The restriction imposed to solve the normal equation

Table 1. Number of animals by breed, sex, year of test and final weight of test animal

\begin{tabular}{|c|c|c|c|c|c|c|c|}
\hline Breed & No. & Sex & No. & Year of test & No. & Final wt. & No. \\
\hline Berkshire & 1,345 & Boar & 1,153 & 2009 & 854 & $\leq 100$ & 185 \\
\hline Duroc & 459 & Gilt & 1,342 & 2010 & 968 & $100-105$ & 287 \\
\hline Lanrace & 245 & & & 2011 & 673 & $105-110$ & 590 \\
\hline \multirow[t]{2}{*}{ Large White } & 446 & & & & & $110-115$ & 1,185 \\
\hline & & & & & & $\geq 115$ & 248 \\
\hline Total & 2,495 & & 2,495 & & 2,495 & & 2,495 \\
\hline
\end{tabular}

Final wt., final weight of test. 
was to assume the last effect within each classification to be zero.

$$
B_{4}=S_{2}=Y_{3}=W_{5}=0
$$

All parameters were analyzed using the generalised linear model (GLM) procedure in SAS ver 6.12 (SAS Institute, 1996). The PROC GLM procedure was used for analysis of variance and the treatment group was set as the class variable. The least squares means (LSM) for each treatment group was computed for group comparison (H0: $\mathrm{LSMi}=\mathrm{LSMj}$ ) using the LSMEANS option in PROC GLM. The PROC CORR procedure was used to compute the phenotypic correlations between meat quality and UIMF percentage. Statistical significance was taken to be $5 \%(\mathrm{p}<$ $0.05)$.

\section{Estimation of genetic parameters}

The following linear model was used to estimate the variance and covariance components of the parameters studied:

$$
Y=X \beta+Z \mathrm{u}+e
$$

where, $\mathrm{Y}$ is a vector of observations ; $\beta$ is a vector of fixed effect (sex, year of test, final weight); $u$ is a vector of random additive genetic effects; $\mathrm{Z}$ and $\mathrm{X}$ are known incidence matrices relating observations to the respective fixed and random effects; and e is a vector of random residual effects.

A derivative-free restriced maximum likelihood algorithm, as applied in the WOMBET programs (Meyer, 1991), was used to estimate components of variance. Solutions for fixed effects and estimated breeding values were obtained from these when convergence was attained. Iterations were stopped when variance of function values in the simplex were less than $1 \times 10^{-10}$. Each analysis was then restarted using the calculated estimates as new priors until changes in the function values were observed.

\section{RESULT AND DISCUSSION}

\section{Effect of breed factors}

Least squares means of the meat quality, UIMF percentage for breed and their respective standard errors are presented in Table $2(\mathrm{p}<0.01)$.

Objective meat quality and palatability are greatly influenced by the $\mathrm{pH}$ of meat due to the effect of $\mathrm{pH}$ on water-holding capacity, protein solubility and surface reflectance (Joo et al., 1999; Hwang et al., 2003). Significant differences in ultimate $\mathrm{pH}$ at $24 \mathrm{~h}$ postmortem were observed in the different breeds used in this study. The ultimate $\mathrm{pH}$ of the Berkshire and Duroc breeds at $24 \mathrm{~h}$ postmortem were higher than the Large White and Landrace breeds $(\mathrm{p}<0.05)$. This result supports the observation by Newcom et al. (2004) and Stalder et al. (2003) that Berkshire and Duroc breeds had higher pigment content than Landrace and Yorkshire breeds. Berger et al. (1994) reported that Hampshire breeds had lower $(\mathrm{p}<0.05) \mathrm{pH}$ than any other breed.

Several studies have demonstrated that the level of IMF percentage greatly influences eating quality (Wood et al., 1996). Significant breed differences for CIMF and UIMF were observed in this study, with the Duroc breed having higher IMF than the Berkshire, Landrace, and Large White breeds $(\mathrm{p}<0.05)$. These results are in agreement partly with the report by Newcom et al. (2004) that Landrace and Yorkshire breeds had higher pigment content than Berkshire and Duroc breeds. The Duroc and Berkshire breeds had the highest $(\mathrm{p}<0.05)$ levels of IMF percentage, which agrees with the findings of Berger et al. (1994).

Significant breed differences for CIE $\mathrm{L}^{*}$ were also observed in this study. The Landrace and Large White breeds had higher CIE L* than the Berkshire and Duroc breeds $(p<0.05)$. This result is also in agreement with the study by Newcom et al. (2004). Additionally, the Duroc, Landrace, and Large White breeds had higher CIE $a^{*}$ and $b^{*}$ than the Berkshire breed $(p<0.05)$ while the Landrace and Large White breeds had higher CL and SF than the

Table 2. Least squares means of the meat quality traits and ultrasound intramuscular fat percentage for breed and their standard errors

\begin{tabular}{lrrrr}
\hline Source & \multicolumn{1}{c}{ Bekshire } & \multicolumn{1}{c}{ Duroc } & Landrace & Large White \\
\hline $\mathrm{pH}_{24 \mathrm{~h}}$ & $5.81^{\mathrm{a}} \pm 0.01$ & $5.83^{\mathrm{a}} \pm 0.02$ & $5.74^{\mathrm{b}} \pm 0.03$ & $5.75^{\mathrm{b}} \pm 0.03$ \\
$\mathrm{CIMF}(\%)$ & $2.40^{\mathrm{b}} \pm 0.04$ & $2.79^{\mathrm{a}} \pm 0.15$ & $2.11^{\mathrm{b}} \pm 0.16$ & $2.23^{\mathrm{b}} \pm 0.16$ \\
$\mathrm{UIMF}(\%)$ & $2.23^{\mathrm{b}} \pm 0.02$ & $2.40^{\mathrm{a}} \pm 0.12$ & $2.10^{\mathrm{b}} \pm 0.13$ & $2.25^{\mathrm{b}} \pm 0.13$ \\
$\mathrm{CIE} \mathrm{L}^{* 1}$ & $43.21^{\mathrm{c}} \pm 0.15$ & $45.75^{\mathrm{b}} \pm 0.59$ & $46.97^{\mathrm{a}} \pm 0.62$ & $76.29^{\mathrm{a}} \pm 0.61$ \\
$\mathrm{CIE} \mathrm{a}^{* 1}$ & $6.85^{\mathrm{b}} \pm 0.07$ & $7.36^{\mathrm{a}} \pm 0.27$ & $7.56^{\mathrm{a}} \pm 0.28$ & $7.50^{\mathrm{a}} \pm 0.28$ \\
$\mathrm{CIE} \mathrm{b}^{* 1}$ & $2.63^{\mathrm{b}} \pm 0.04$ & $3.07^{\mathrm{a}} \pm 0.17$ & $2.93^{\mathrm{a}} \pm 0.18$ & $2.64^{\mathrm{ab}} \pm 0.17$ \\
$\mathrm{CL}(\%)$ & $24.94^{\mathrm{b}} \pm 0.28$ & $24.37^{\mathrm{b}} \pm 0.65$ & $26.34^{\mathrm{a}} \pm 0.69$ & $26.25^{\mathrm{a}} \pm 0.68$ \\
$\mathrm{SF}(\mathrm{N})$ & $34.68^{\mathrm{b}} \pm 0.30$ & $34.75^{\mathrm{b}} \pm 1.52$ & $44.60^{\mathrm{a}} \pm 1.60$ & $44.89^{\mathrm{a}} \pm 1.58$ \\
\hline
\end{tabular}

$\mathrm{pH}_{24 \mathrm{~h}}$, ultimate $\mathrm{pH}$ at $24 \mathrm{~h}$ postmortem; CIMF, chemical intramuscular fat percentage; UIMF, ultrasound intramuscular fat percentage; CIE, Commission Internationale de 1'Eclairage; CL, cooking loss; SF, shear force.

${ }^{1} \mathrm{CIE} \mathrm{L}^{*}=$ black (0) to white (100) scale; CIE a* = red (+) to green (-) color scale; CIE b* = yellow (+) to blue (-) color scale.

a,b,c Values in the same row within the same fixed effect that do not have a common superscript differ $(\mathrm{p}<0.05)$. 
Table 3. Heritabilities (diagonal), genetic correlations (above diagonal) and phenotypic correlations (below diagonal) among meat quality traits and ultrasound intramuscular fat percentage

\begin{tabular}{|c|c|c|c|c|c|c|c|c|}
\hline Traits $^{1}$ & $\mathrm{pH}_{24 \mathrm{~h}}$ & CIMF & UIMF & CIE L $*^{2}$ & CIE $a^{*^{2}}$ & $\mathrm{CIE} b^{*^{2}}$ & $\mathrm{CL}$ & SF \\
\hline$\overline{\mathrm{pH}_{24 \mathrm{~h}}}$ & 0.52 & $-0.15^{\mathrm{ns}}$ & $-0.14^{\mathrm{ns}}$ & $-0.45 * *$ & $-0.28 *$ & $-0.42 *$ & $-0.17 *$ & $0.07^{\mathrm{ns}}$ \\
\hline CIMF & $-0.02^{\mathrm{ns}}$ & 0.50 & $0.75 * *$ & $0.27 * *$ & $0.37 * *$ & $0.48 *$ & $-0.03 *$ & $-0.23^{\mathrm{ns}}$ \\
\hline UIMF & $-0.01^{\mathrm{ns}}$ & $0.76^{* *}$ & 0.48 & $0.24 * *$ & $0.3 * *$ & $0.41 *$ & $-0.01 *$ & $-0.04^{\mathrm{ns}}$ \\
\hline CIE L $*^{2}$ & $-0.49 *$ & $0.17 * *$ & $0.15^{*}$ & 0.51 & $0.21 * *$ & $0.79 * *$ & $0.23^{* *}$ & $-0.13 *$ \\
\hline CIE $a^{*^{2}}$ & $-0.1^{\mathrm{ns}}$ & $0.21 * *$ & $0.22 *$ & $-0.08 *$ & 0.52 & $0.63 * *$ & $0.13 *$ & $-0.01 *$ \\
\hline $\mathrm{CIE} b^{* 2}$ & $-0.16^{*}$ & $0.28 *$ & $0.25 *$ & $0.64 * *$ & $0.39 * *$ & 0.48 & $0.15 *$ & $-0.11^{\mathrm{ns}}$ \\
\hline CL & $-0.11 *$ & $0.11 *$ & $-0.17^{\mathrm{ns}}$ & $-0.28 * *$ & $-0.01^{\mathrm{ns}}$ & 0.09 & 0.46 & $-0.04^{\mathrm{ns}}$ \\
\hline SF & $0.08^{\mathrm{ns}}$ & $-0.03^{\mathrm{ns}}$ & $0.01^{\mathrm{ns}}$ & $-0.03 *$ & $0.11 *$ & $-0.05^{\mathrm{ns}}$ & $0.33^{* *}$ & 0.56 \\
\hline
\end{tabular}

${ }^{1} \mathrm{pH}_{24 \mathrm{~h}}$, ultimate $\mathrm{pH}$ at $24 \mathrm{~h}$ postmortem; CIMF, chemical intramuscular fat percentage; UIMF, ultrasound intramuscular fat percentage; CIE, Commission Internationale de l'Eclairage; CL, cooking loss; SF, shear force.

${ }^{2} \mathrm{CIE} \mathrm{L}^{*}=$ black (0) to white (100) scale; CIE $\mathrm{a}^{*}=$ red (+) to green $(-)$ color scale; CIE $\mathrm{b}^{*}=$ yellow $(+)$ to blue (-) color scale.

$* * \mathrm{p}<0.01, * \mathrm{p}<0.05 ; \mathrm{ns}$, not significance.

Berkshire and Duroc breeds $(\mathrm{p}<0.05)$.

Heritability, estimates of meat quality traits and ultrasound intramuscular fat percentage

Genetic parameter estimates for meat quality traits and UIMF percentage are displayed in Table 3 . The heritability estimate for ultimate $\mathrm{pH}$ was determined to be 0.33 , which is higher than the value reported by Larzul et al. (1997) and Suzuki et al. (2005). The heritability estimates for CIMF and UIMF were calculated to be 0.50 and 0.48 , respectively. Both values were higher than the values reported by Newcom et al. (2005). The calculated CIE L*, a*, and b* values of $0.51,0.50$, and 0.48 , respectively, were lower than the values reported by Newcom et al. (2003). A previous review by Sellier (1998) determined that the average heritability for CIE L* was 0.28 using data from 29 published estimates with a range of 0.15 to 0.57 , which was lower than the estimate found in this study. The CL and SF were determined to have moderate heritability ( 0.46 and 0.56). Suzuki et al. (2005) also reported the heritability for drip loss and CL as $0.14 \pm 0.01$ and $0.09 \pm 0.02$, which was lower than the estimate found in this study.

Genetic and phenotypic correlations among meat quality traits and ultrasound intramuscular fat percentage

Genetic and phenotypic correlations between ultimate $\mathrm{pH}$ and CIMF were -0.15 and -0.02 , respectively. A higher negative genetic correlation of -0.51 was reported by Suzuki et al. (2005). Genetic and phenotypic correlations between ultimate $\mathrm{pH}$ and UIMF were -0.14 and -0.01 , respectively. Genetic and phenotypic correlations between ultimate $\mathrm{pH}$ and meat color were negative, in agreement with findings by Suzuki et al. (2005). This relationship is also supported by other reports (DeVol et al., 1988; Hovenier et al., 1992). Conversely, pork with a low ultimate $\mathrm{pH}$ can be lighter in color (Monin and Sellier, 1985).

Estimates of genetic and phenotypic correlations for
CIMF and UIMF were 0.75 and 0.76 , which were strong correlations. This correlation suggests that CIMF can be replaced with UIMF and that ultrasound machines can be used to determine IMF in live swine.

In this study, the range of genetic correlations between IMF (CIMF and UIMF) and CIE L*, CIE $a^{*}$, CIE $b *$ were 0.24 to $0.27,0.30$ to 0.37 , and 0.41 to 0.48 , respectively. These results are similar to results reported by Suzuki et al. (2005). The range of genetic correlation between IMF (CIMF and UIMF) and CL was determined to be 0.01 to 0.03. This was in agreement with Hovenier (1992), but not with Suzuki et al. (2005). Genetic and phenotypic correlations between meat color (CIE L*, CIE a*, CIE b*) and CL were 0.13 to 0.23 and 0.28 to 0.29 , respectively. The genetic and phenotypic correlations between CL and SF were estimated to be 0.24 and 0.33 , respectively.

\section{CONCLUSION}

Four breeds, Berkshire, Duroc, Landrace, Large White were measured for loin muscle IMF percentage by ultrasound machine (UIMF) in live swine. The number of pigs were 2,495 heads. All the pigs tested were sacrificed and their loin muscles were analysed to determine the CIMF percentage.

These results suggest that genetic factors strongly influence meat quality. The genetic and phenotypic correlation between UIMF and CIMF were 0.75 and 0.76 , respectively. The heritabilities of UIMF and CIMF were 0.48 and 0.50 , respectively. Genetic correlations between UIMF, CIMF, and $\mathrm{pH}_{24 \mathrm{~h}}$ were -0.15 and -0.14 , respectively. $\mathrm{pH}_{24 \mathrm{~h}}$ is one of the more important indicators for pork quality. In conclusion, UIMF can be utilized to improve pork quality as an alternative to CIMF.

\section{ACKNOWLEDGMENTS}

This work was supported by grant from Yu-dang, Ji 
Sung Yang Memorial Fund.

\section{REFERENCES}

Albrecht, E., J. Wegner, and K. Ender. 1996. A new technique for objective evaluation of marbling in beef. Fleischwirtschaft 76:1145-1148.

Barton-Gade, P. A. 1990. Pork quality in genetic improvement programmes - the Danish experience. Proceeding of the National Swine Improvement Federation Annual Meeting. Des Moines, IA, USA.

Basset, O., B. Buquet, S. Abouelkaram, P. Delachartre, and J. Culioli. 2000. Application of texture image analysis for the classification of bovine meat. Food Chem. 69:437-445.

Bligh, E. G. and W. J. Dyer. 1959. A rapid method of total lipid extraction and purification. Can. J. Biochem. Physiol. 3:911917.

Berger, P. J., L. L. Christian, C. F. Louis, and J. R. Mickelson. 1994. Estimation of genetic parameters for growth, muscle quality, and nutritional content of meat products for centrally tested purebred market hogs. National Pork Production Council 1994, Des Moines, IA, USA. Research Investment Report pp. 51-63.

Brewer, M. S., L. G. Zhu, and F. K. McKeith. 2001. Marbling effects on quality characteristics of pork loin chops: Consumer purchase intent, visual and sensory characteristics. Meat Sci. 59:153-163.

Cross . H. R. and K. E. Belk. 1994. Objective measurements of carcass and meat quality. Meat Sci. 36:191-202.

DeVol, D. L., F. K. McKeith, P. J. Bechtel, J. Novakofski, R. D. Shanks, and T. R. Carr. 1988. Variation in composition and palatability traits and relationships between muscle characteristics and palatability in a random sample of pork carcasses. J. Anim. Sci. 66:385-395.

Edwards . J. W., R. C. Cannell., R. P. Garrett., J. W. Savell, H. R. Cross, and M. T . Longnescker. 1989. Using ultrasound, linear measurements and live fat thickness estimates to determine the carcass composition of market lambs. J. Anim. Sci. 67:33223330.

Forrest. J. C., C. H. Kure., M. W. Orecutt., A. P. Schinkel., J. R. Stouffer., and M. D. Judge. 1989. A review of potential new methods of on-line pork carcass evaluation. J. Anim. Sci. 67:2164-2170.

Harvey, W. R. 1979. Least Squares analysis of data with unequal subclass numbers. Report ARS H-4, USDA, ARS-H-4, SEA, Washington, DC, USA.

Hovenier, R., E. Kanis, T. H. van Asseldonk, and N. G. Westerink. 1992. Genetic parameters of pig meat quality traits in a halothane negative population. Livest. Prod. Sci. 32:309-321.

Hwang, I. H., C. E. Devine, and D. L. Hopkins. 2003. The biochemical and physical effects of electrical stimulation on beef and sheep meat tenderness. Meat Sci. 65:677-691.

Joo, S. T., R. G. Kauffmann, B. C. Kim, and G. B. Park. 1999. The relationship of sarcoplasmic and myofibrillar protein solubility to colour and water-holding capacity in porcine longissimus muscle. Meat Sci. 52:291-297.

Larzul, C., L. Lefaucheur, P. Ecolan, J. Gogue, A. Talmant, P. Sellier, P. Le Roy, and G. Monin. 1997. Phenotypic and genetic parameters for longissimus muscle fiber characteristics in relation to growth, carcass, and meat quality traits in Large White pigs. J. Anim. Sci. 75:3126-3137.

Monin, G. and P. Sellier. 1985. Pork of low technological quality with a normal rate of muscle $\mathrm{pH}$ fall in the immediate postmortem period: The case of the Hampshire breed. Meat Sci. 13:49-63.

Meyer, K. 1991. Estimation of variance components for Individual Animal Models II. Multivariate analyses. Genet. Sel. Evol. 23:67-83.

Newcom, D. W., T. J. Baas, and R. N. Goodwin. 2003. Relationship between intramuscular fat percentage predicted from real-time ultrasound and meat quality traits in pigs. J. Anim. Sci. 81(Suppl. 2):35. (Abstr.)

Newcom, D. W., T. J. Baas, and J. F. Lampe. 2002. Prediction of intramuscular fat percentage in live swine using real-time ultrasound. J. Anim. Sci. 80:3046-3052.

Newcom, D. W., K. J. Stalder, T. J. Baas, R. N. Goodwin, F. C. Parrish, and B. R. Wiegand. 2004. Breed differences and genetic parameters of myoglobin concentration in porcine longissimus muscle. J. Anim. Sci. 82:2264-2268.

Newcom, D. W., T. J. Baas, K. J. Stalder, and C. R. Schwab. 2005. Comparison of three models to estimate breeding values for percentage of loin intramuscular fat in Duroc swine. J. Anim. Sci. 83:750-756.

Ragland, K, D., J. Brondum., L. L. Christian. 1997. Prediction of intramuscular fat in live swine using real-time ultrasound. Proceedings National Swine Improvement Federation Conference Annual Meeting, December 5-6, 1997; Des Moines, Iowa, USA. 22:117.122.

SAS. 2007. SAS/STAT Software for PC, Release 9.0, SAS Institute Inc., Cary, NC, USA.

Schworer, D. A., A. Rebsamen, and D. Lorenz. 1995. Selection of intramuscular fat in Swiss pig breeds and the importance of fatty tissue quality. Proceeding of 2nd Dummerstorf Muscle Workshop on Growth and Meat Quality, Rostock, Germany.

Sellier, P. 1998. Genetics of meat and carcass traits. The Genetics of the Pigs (Eds. M. F. Rothschild and A. Rubinsky). CAB Int., New York, NY, USA. pp. 463-510.

Stalder, K. J., R. C. Lacy, T. L. Cross, and G. E. Conaster. 2003. Financial impact of average parity of culled females in a breed-to-wean swine operation using replacement gilt net present value analysis. J. Swine Health Prod. 11:69-74.

Suzuki, K., M. Irie, H. Kadowaki, T. Shibata, M. Kumagai, and A. Nishida. 2005. Genetic parameter estimates of meat quality traits in Duroc pigs selected for average daily gain, longissimus muscle area, backfat thickness, and intramuscular fat content. J. Anim. Sci. 83:2058-2065.

Terry, C. A., J. W. Savell, H. A. Recio, and H. R. Cross. 1989. Using ultrasound technology to predict pork carcass composition. J. Anim. Sci. 67:1279-2884.

Wood, J. D., S. N. Brown, G. R. Nute, F. M. Whittington, A. M. Perry, S. P. Johnson, and J. M. Enser. 1996. Effects of breed, feed level and conditioning time on the tenderness of pork. Meat Sci. 44:105-112.

Yang, X. J., E. Albrecht, K. Ender, R. Q. Zhao, and J. Wegner. 2005. Computer image analysis of intramuscular adipocytes and marbling in the longissimus muscle of cattle. J. Anim. Sci. $84: 3251-3258$. 